\title{
Utilization of damaged and spoiled wheat grains for bioethanol production
}

\author{
Nadia Razdan* and G.S. Kocher \\ Department of Microbiology, Punjab Agricultural University, Ludhiana-141004, India
}

\begin{abstract}
First generation ethanol from starchy crops particularly maize is an established technology that being a renewable and bio-based resource has advantages over gasoline. The second generation ethanol from lignocellulosics owing to its economic considerations is still at pilot scale and is yet to see commercialization. This has increased the demand of starchy feed-stocks for energy. The recently released National Policy on Biofuels in May, 2018 categorically also emphasizes on the potential of different raw materials for ethanol production by consenting the utilization of damaged food grains like wheat, broken rice etc. that area otherwise unfit for human consumption. As far as wheat is concerned, The Comptroller and Auditor General (CAG), India (2017) reported that Food Corporation of India's (FCI) wheat stock worth 700 crores was damaged solely in Punjab from 2011 to 2016 as the grain was kept in open areas attributed to the lack in storage facility. Development of efficient technology to pretreat and convert damaged starch into fermentable sugars and optimization of enzymatic hydrolysis using commercial as well as indigenous enzyme preparation are the key points for the efficient bioethanol production from damaged wheat. Further, the synergistic action of alpha and glucoamylase in the hydrolysis of wheat mash have been tried that has revealed 96.25\% conversion efficiency with an ethanol yield $5.60 \%(\mathrm{v} / \mathrm{v})$. The present review discusses research progress in bioethanol production from damaged wheat grains containing higher starch content. Thus, utilization of especially damaged and spoiled wheat grains pave better way for commercialization of bioethanol production from an economical perspective.
\end{abstract}

KEY WORDS: BIOTHANOL, INDIGENOUS, LIGNOCELLULOSICS, DAMAGED WHEAT

\section{ARTICLE INFORMATION:}

Corresponding Authors: nadiarazdan2012@gmail.com Received 25 $5^{\text {th }}$ Oct, 2018

Accepted after revision $24^{\text {th }}$ Dec, 2018

BBRC Print ISSN: 0974-6455

Online ISSN: 2321-4007 CODEN: USA BBRCBA Thomson Reuters ISI ESC / Clarivate Analytics USA

Mono of Clarivate Analytics and Crossref Indexed Journal Mono of CR

NAAS Journal Score 2018: 4.31 SJIF 2017: 4.196

( $)$ A Society of Science and Nature Publication, Bhopal India 2018. All rights reserved.

Online Contents Available at: http//www.bbrc.in/

DOI: $10.21786 / \mathrm{bbrc} / 11.4 / 17$ 


\section{INTRODUCTION}

Global demand for energy sources and their utilization determine the economic status and growth of developing countries all over the world (Xu and Liu 2009). The major energy demand is still supplied from conventional fossil fuels such as oil, coal and natural gas which don't regenerate at sustainable manners (Twidell and Weir 2003). Fossil Fuels have played an indispensible role in development of industry but its indiscriminate use and the resulting environmental pollution led to advent of alternate fuels. The Energy Information Administration (EIA) reported that 70\% of oil consumed in the United States was used for transportation (EIA 2015 a). According to EIA's 2014 report, 27\% of petroleum consumed in the United State was imported from foreign countries (EIA 2015b). Hence, use of renewable resources to produce liquid biofuels offer attractive solutions to reducing greenhouse gas emissions, decreasing reliance on foreign oils, addressing energy security concerns, strengthening rural and agricultural economies and increasing the sustainability of the world transportation system. Today, Bioethanol has long been regarded as a suitable substitute to fossil fuels. It has immense properties such as higher compression ratio, shorter burn time and leaner burn engine, which lead to theoretical efficiency advantages over gasoline (Hansen et al 2005). Brazil has the world's first sustainable bioethanol economy with 6.19 billion gallons produced in 2014, which represents over $25 \%$ of the world's ethanol fuel and is ranked second in the world next to the United States (Biofuels 2016).

According to the Renewable Fuels Association (RFA 2018), the global production of bioethanol stood at 27 billion gallons in the year 2017, with the USA $(15,800$ million gallons) and Brazil (7,600 million gallons) as the largest producers in the world. India ranks eighth in ethanol production next to EU, China, US and Brazil with a total production of 280 million gallons in 2017 (RFA, 2018).

The first and second generation bioethanol are commonly referred as first generation bioethanol resources and third type as second generation bioethanol resources. The shift from first to second generation bioresources is obligatory due to main reasons; one is that first generation bio resources have alternate uses such as food (sugarcane, corn), animal feed (molasses) etc, secondly that these are still unable to meet the global demand of bioethanol. On the other hand, Lignocellulosics need costly steps of pretreatment and range of enzyme requirement for saccharification which is making bioethanol production from lignocellulosics a costly affair. In this scenario, there is need for a suitable economical substitute as an alternative. Therefore the National Policy on Biofuels -2018 categorically emphasis on the potential of different raw materials for ethanol production by consenting the utilization of sugarcane juice, sugar containing materials like sugar beet, sweet sorghum, starch containing materials like corn, cassava, damaged food grains like wheat, broken rice, rotten potatoes, unfit for human consumption. India is an agricultural country where wheat and rice are staple food for its burgeoning population. In terms of production, India stands second after china in wheat and rice production accounting for about 200MT/year out of this about 12MT (6\%) of grains are damaged by post-harvest storage due to poor storage facilities and hence damaged by insects, rodents, birds and microbial spoilage (Sharon et al 2014). As far as wheat is concerned, Comptroller and Auditor General (CAG) (2017) reported that Food Corporation of India's (FCI) wheat stock worth 700 crore was damaged solely in Punjab from 2011 to 2016 as the grain was kept in open areas attributed to the lack in storage facility (Anonymous 2017). All this damaged grains were disposed off as they were not fit for consumption by human and animals. However, the damaged grains can be put to application by producing ethanol from its starch content which constitutes $70-80 \%$ in wheat and rice. Theoretically, 30gal/MT of ethanol from damaged wheat and rice may be obtained (Gawande and Patil 2015). Wheat starch is comprised of one quarter amylose and around three quarters amylopectin with little protein and lipid debasements (0.8\% and 0.2\% respectively) (Bowler et al 1985).

The process of grain bioethanol production involves milling (grinding and pretreatments), mashing (enzymatic or acid hydrolysis, steaming, adding supplements etc) and Fermentation (SHF or SSF) which is followed by distillation and dehydration to produce anhydrous ethanol. The conversion of starch to ethanol can be accomplished by acid hydrolysis, but the generation of by products such as levulinic and formic acid may cause hampered yeast growth hence, lower yields of alcohol (Kerr 1944). The acid hydrolysis has now been largely switched with amylolytic enzymes ( $\alpha$-amylase and glucoamylase) which deliver 95\% more yield of glucose (Hua and Yang 2016).

Though using damaged grains will incur lower substrate cost, mashing involves costly commercial saccharification and enzymes which may also be taken care of by using indigenous culture of Bacillus subtilis, Bacillus circulans, Bacillus cereus etc for $\alpha$-amylase and Aspergillus such as Aspergillus niger, Aspergillus oryzae etc for glucoamylase. Fermentation is the final stage performed after starch pretreatment (digestion) for bioethanol production The process cost may be further be reduced by using Simultaneous Saccharification and Fermentation as it reduces the time as well as energy by using two different vessels for Saccharification and 
Fermentation besides lowering the chances of contamination. This review designed to provide an insight into the process details as well as the update of the damaged cereals particularly damaged wheat for bioethanol production.

\section{FEEDSTOCKS FOR BIOETHANOL PRODUCTION}

The raw materials for bioethanol production can broadly be classified as (i) sucrose-containing feedstock (sugarcane, sugar beet and sweet sorghum) (ii) starch-containing feedstock (wheat, corn and cassava) and (iii) cellulosic feedstock (straw, grasses, wood, stovers, agricultural wastes and paper etc) (Table 1) while the bioethanol produced from sucrose-and starch-containing feedstock is classified as 1st generation bioethanol (ethanol from corn and sugarcane) that produced utilizing cellulosic feedstock is referred as $2^{\text {nd }}$ generation bioethanol. The source of third generation biofuel is lipolytic compounds obtained predominantly from algae. Most current bioethanol production processes utilize more readily degradable biomass feedstock such as cereals (corn and grain) and molasses. However, the utilization of edible agricultural crops exclusively for biofuel production conflict with food and feed production (Wheals et al 1999). One of the major problems with bioethanol production is the variability in available raw materials as their geographic locations differ from season to season, place to place and price of substrates which affects and hence the production cost of bioethanol (Kumar 2006; Yoosin et al 2007).

\section{UTILIZATION OF DAMAGED CEREAL GRAINS FOR BIOETHANOL PRODUCTION}

Cereal grains are used mostly for food and feed. However, post heat losses from farm to fork take a significant portion of damaged/infested cereal grains which are not fit for consumption. But there are rich sources of sugar (in the form of starch) just like simple sugar substances such as molasses, sugarcane juice can be fermented. These starch based materials like corn, rice and wheat have infact proved to be promising raw materials for their efficient fermentation into industrial as well as potable ethanol with the help of appropriate fermenting micro-organisms (Awasthi et al 2015). As per estimates provided by Food Corporation of India (FCI) huge quantities of cereal grains are getting spoiled every year due to unfavourable climate conditions and become unfit for human and animal consumption and one million tonnes of damaged grains is lying unutilised in FCI stores (Kumar et al 1999). The damage includes discoloration, breakage, cracking, attack by fungi, insect damage, chalky grain, partial softening due to dampness, off smell etc (Gawande and Patil 2015).
The damaged grains used for ethanol production are ten times cheaper than fine quality. These damaged or waste cereal grains can be utilized for the effective production of ethanol using fermentation process which will not only meet (partially) our needs but may provide some incentive to the farmers who suffers due to crop damage. The chemical composition of cereal grains is characterized by the high content of carbohydrates mainly starch (56-74\%) deposited in the endosperm and fibre in the bran (2-13\%). The second important group of constituents is the proteins which fall within an average range of about 8-11\% and high content of B-vitamins is, in particular, of nutritional relevance. Hence, spoiled and damaged starchy grains can also be used for bioethanol production.

\section{DAMAGED WHEAT: A PROMISING RAW MATERIAL FOR BIOETHANOL PRODUCTION}

\section{Global Scenario of wheat}

Wheat is produced in 120 countries and accounts for about 19 per cent of the world's calorie supplies. It is used primarily as flour for making bread, pastry, pasta and noodles etc. It is also used to feed livestock, with the feed accounting for about 17 per cent of global wheat consumption. In addition, the by-products from milling of wheat into flour are also used as feed. The annual global production of dry wheat is about $529 \mathrm{Tg}$ whereby Asia (43\%) and Europe (32\%) are the primary producers. Like rice, China is the largest producer of wheat with about $18 \%$ of global production at an average yield of 3:4 dry $\mathrm{mg} \mathrm{ha}^{-1}$. The second largest producer is India, where dry wheat production is $71 \mathrm{Tg}(12 \%)$, and the yield is 2:4 dry $\mathrm{mg} \mathrm{ha}^{-1}$ (Seungdo et al 2004).

India produces wheat in appreciable amount that can be a very good raw material for bioethanol production. Secondly, a huge quantity of wheat is wasted every year due to mismanagement; lack of proper storing facilities in the warehouses and spoiled wheat can also be utilized for bioethanol production. In the present Indian scenario as per estimates provided by Food Corporation of India (FCI) huge quantities of cereal grains are getting spoiled every year due to unfavorable climatic conditions and become unfit for human and animal consumption. There are about one million tons of damaged and spoiled grains lying unutilized in FCI stores (Kumar et al 1999).

As far as wheat is concerned, Comptroller and Auditor General (CAG) (2017) reported that Food Corporation of India's (FCI) wheat stock worth 700 crores was damaged solely in Punjab from 2011 to 2016 as the grain was kept in open areas attributed to the lack in storage facility (Anonymous 2017). All this damaged grains were disposed off as they were not fit for consumption 
by human and animals. Belboom et al (2015) reported that the consumption of $1 \mathrm{MJ}$ bioethanol produced from wheat instead of $1 \mathrm{MJ}$ gasoline can reduce greenhouse gas emissions by $42.5-61.2 \%$.

\section{Structure and composition of wheat grain}

Wheat, derived from the wild (Triticum aestivum L.) is today the fifth major cereal plant cultivated in the world (Fig 2.1). Besides growing wheat for food purposes, there is also an interest in wheat cultivars for non-food and technical uses starch and bioethanol production (Kust and Potmesilova 2014). Damaged wheat grains could be an economical carbon source for ethanol fermentation in the industry, because of high starch content and low commercial value. Yan et al (2010) tested field-sproutedsorghum and concluded that the use of these kernels significantly reduced fermentation time and yielded higher ethanol. Starch or amylum is a polymeric carbohydrate comprising of a large number of glucose units joined by glycosidic bonds and contains two main structural components, amylose and amylopectin. Amylose is essentially a linear polymer in which the glucose residues are connected by the $\alpha-1,4$ linkages. The other main component of starch is amylopectin, which is a larger and branched molecule with both $\alpha-1,4$ and $\alpha-1,6$ linkages. Most native wheat starch is a mixture of amylose and amylopectin, in the ratio of $1: 3$ by weight. The content of amylose in wheat starch generally ranges from 20-26\% (Buresova et al 2010).

\section{STARCH HYDROLYSIS}

In industry, starch is converted into sugars or fermented to produce ethanol. Starch cannot be metabolized directly by yeast, but must first be broken down into simple six carbon sugars (glucose) prior to fermentation. The conversion of starch-containing feedstock to obtain fermentable sugars is mainly comprised of three opera- tions which are: (i) milling, (ii) liquefaction and (iii) saccharification using enzymes.

The first stage of starch hydrolysis is gelatinization which is to break down the intermolecular bonds of starch with heat in the presence of water. Starch granules are quite resistant to penetration by both water and hydrolytic enzymes due to the formation of hydrogen bonds within the molecule and other molecules. However, these intra and inter- hydrogen bonds are weakened during gelatinization. During this stage, the temperature of aqueous suspension of starch is elevated, the water absorption and expanded granules dissolving starch granules to form a viscous suspension or slurry. This allows disruption or burst of the starch granules and exposes it to enzyme attack. This process is known as gelatinization and the temperature at which starch properties are changed is named as gelatinization temperatures (Albani 2008). The susceptibility of starch to amylase attack depends on the properties of the specific starch, such as e.g. degree of gelatinization and the characteristics of the specific amylase (Bijttebier et al 2008). Different starches have different gelatinization temperatures, implying different ease of cooking. Cassava starch has a lower temperature, relatively to cereal starches; the pasting temperatures for cassava, corn, wheat and rice are $60-65^{\circ} \mathrm{C}, 75-80^{\circ} \mathrm{C}, 80-85^{\circ} \mathrm{C}$ and $73-75^{\circ} \mathrm{C}$, respectively (Swinkels 1998; Thirathumthavorn and Charoenrein 2005). The physicochemical properties of starch impose limitations in the use of higher starch concentrations as a result of gelatinization of the starch which causes undesirable viscosity development.

Liquefaction is a step that starch is degraded by an endo-acting enzyme namely alpha -amylase (EC 3.2.1.1) which hydrolyzes only $\alpha-1,4$ and causes dramatically drop in viscosity of cooked starch. Typically, liquefying enzymes can have an activity at a high temperature ( $>$ $85^{\circ} \mathrm{C}$ ) so that the enzyme can help reduce paste viscosity of starch during cooking. The dextrins, i.e. products

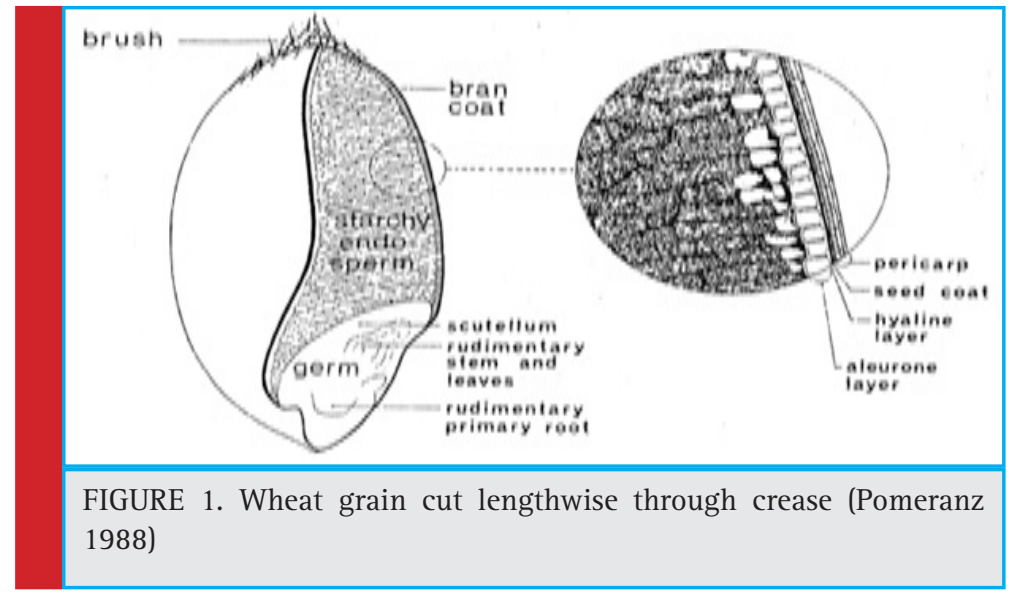


obtained after liquefaction, is further hydrolyzed ultimately to glucose by glucoamylase enzyme which can hydrolyze both $\alpha-1,4$ and $\alpha-1,6$ glycosidic linkage in amylase and amylopectin branches of starch. Glucoamylase (GA), also known as amyloglucosidase (EC 3.2.1.3), is an inverting type and exo-acting enzyme, capable of hydrolyzing $\alpha-1,4$ glycosidic linkages in raw or soluble starches and related oligosaccharides with the inversion of the anomeric configuration to produce glucose.

The starch-based bioethanol industry has been commercially viable for about 30 years; in that time, tremendous improvements have been made in enzyme efficiency, reducing process costs, time, increasing hydrolysis and bioethanol productivity. Hydrolysis of starch may be considered as a key step in the processing of starch-based feedstock for the bioethanol production. Starch can be hydrolyzed by acid, acid-enzyme and enzyme-enzyme techniques.

\section{Acid hydrolysis (lintnerization)}

Acid hydrolysis is an important chemical modification that can significantly change the structural and functional properties of starch without disrupting its granular morphology. During acid hydrolysis, amorphous regions are hydrolysed preferentially, enhancing the crystallinity and double helical content of acid hydrolyzed starch (Wang and Copeland 2013). According to Dziedzic and Kearsley (2012) acid hydrolysis was discovered at the beginning of the $19^{\text {th }}$ century by boiling wheat starch with dilute sulphuric acid results in a sweet syrup. Later, potato starch was used as the starch source and sulphuric acid was replaced by hydrochloric acid and indirect heating of the reaction vessel was common practice. Since then, acid has been used to a great extent for the breakdown of starch into glucose particularly in industry. Bej et al (2008) had investigated on concentrated acid hydrolysis $\left(\mathrm{H}_{2} \mathrm{SO}_{4}\right)$ of wheat flour in a batch reactor at different temperatures and acid concentrations. A maximum conversion (42\%) of starch to the reducing sugars was obtained at $95^{\circ} \mathrm{C}$ and $\mathrm{pH} 3$.

Similarly, Hoseinpour et al (2010) showed that hydrolysis of starch using dilute sulphuric acid leads to complete conversion to glucose under optimum conditions of $130^{\circ} \mathrm{C}, 1 \%$ acid and $7.5 \%$ solids loading for 30 minutes. The mineral acid or acid-base involved in the hydrolysis can be of diluted or concentrated form and dilute acid process at 1-5\% concentration is conducted under high temperature, pressure and has fast reaction. The concentrated acid process on the other hand uses relatively mild temperatures and reaction times are typically much longer as compared to dilute acid hydrolysis. The biggest advantage of dilute acid processes is their fast reaction rate, which facilitates continuous processing for hydrolysis of both starch and cellulosic materi- als. Their prime disadvantage however is the low sugar yield and this has opened up a new challenge to increase glucose yields higher than 70\% (especially in cellulosic material) in an economically viable industrial process while maintaining high hydrolysis rate and minimizing glucose decomposition (Xiang et al 2004; McConnell 2008). The concentrated acid hydrolysis offers high sugar recovery efficiency, up to $90 \%$ of both hemicelluloses and cellulose sugars. However, this technique does have a number of drawbacks such as relatively low yield and formation of undesirable by-products (Ramprakash and Muthukumar 2014).

\section{Enzymatic hydrolysis}

In the last decade, the starch industry has transformed from using acid in the hydrolysis process to enzyme. The acid was largely replaced by enzyme which gives 95\% more yield of glucose (Hua and Yang 2016). Enzymatic hydrolysis of starch requires two types of enzymes due to the fact that starch or amylum comprises of two major components, namely amylose, a mainly linear polysaccharide consisting of $\alpha$-1,4-linked $\alpha$-glucopyranose units and the highly branched amylopectin fraction that consists of $\alpha-1,4$ and $\alpha$-1,6-linked $\alpha$-glucopyranose units (Knox et al 2004). These two types of linkages, $\alpha-1,4$ and $\alpha-1,6-$ linked required an efficient starch hydrolysis agent or enzyme that can fraction $\alpha-1,4$ and promote $\alpha-1,6$ debranching activity which leads to a reduction in viscosity of gelatinized starch in the liquefaction process. There are certain type of carbohydratedegrading enzymes include a -amylases, b -amylases, debranching enzymes, cellulases, $\mathrm{b}$-glucanases and glucosidases etc. The process of enzyme hydrolysis involves hydration of starch by heating the starch in aqueous suspension to give $\alpha$-amylase an access to hydrolyze the starch (Fig 2). Exoamylases such as glucoamylase is added during saccharafication which hydrolyses 1,4 and 1,6-alpha linkages in liquefied starch(Maarel et al 2002).The important advantages of the saccharification of starch by the amylase mode include higher yield and purity, easy crystallization, better process control, lower cost of production, ion exchange capacity, significant reduction in energy requirement, elimination of heavy depreciations on expensive corrosion resistant equipment, production of new products and formation of lower by-products (Barfoed 1967; Madsen and Norman 1973; Fullbrook 1984).

\section{MICROBIAL DIVERSITY INVOLVED IN AMYLASE PRODUCTION}

The amylolytic microorganisms have immense applications in industries as well as in scientific research as they are more stable when compared with plant and ani- 


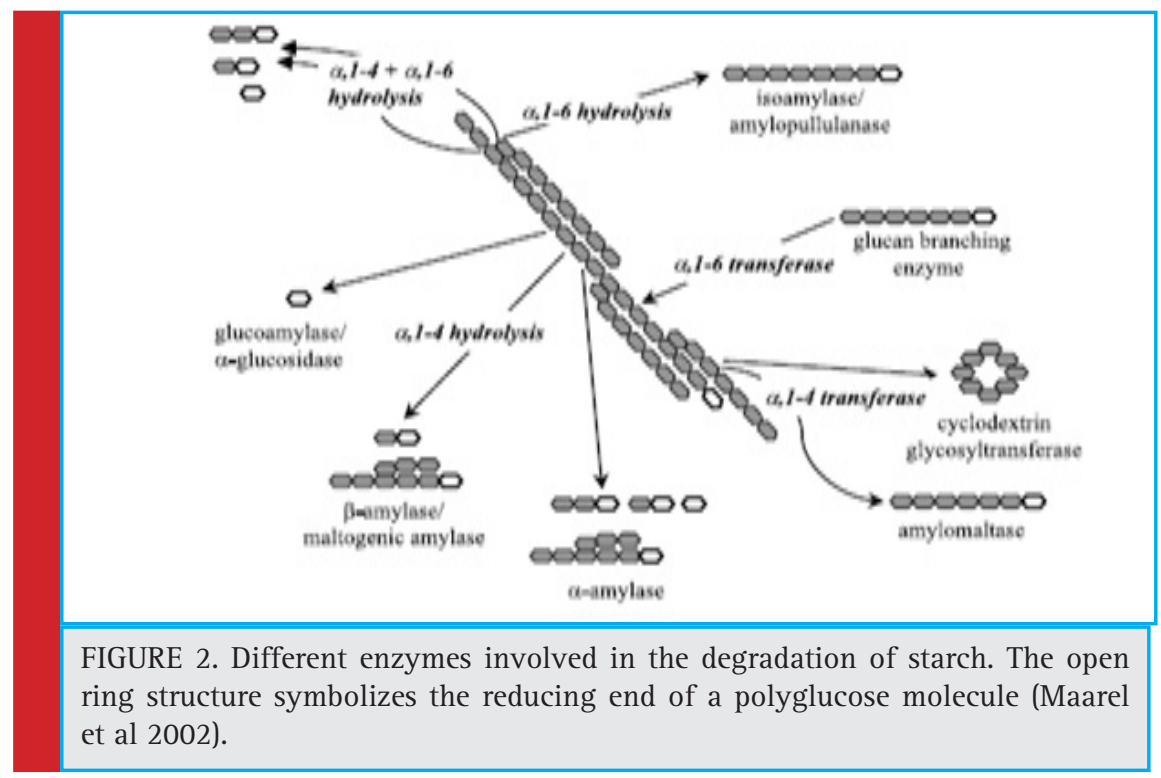

mal amylase. The major advantage of using microorganisms for the production of amylases is the economical bulk production capacity and the fact that microbes are easy to manipulate to obtain enzymes of desired characteristics. Though amylases are produced by several fungi, yeast, bacteria and actinomycetes, but only a few selected strains of fungi and bacteria meet the criteria for commercial amylase production (Table 1).

\section{Microbial production of alpha amylase}

Profiling microorganisms with high potential for amylase production in submerged fermentation (SmF) using synthetic media has been widely recognized due to their myriad applicability in bioethanol production. Raplong et al (2014) identified Bacillus using mannitol egg yolk polymyxin B (MYP) agar a highly selective media.They reported that Bacillus cereus strain SB2 had largest zone of hydrolysis of $12 \mathrm{~mm}$ on nutrient agar supplemented with starch. Amylase activity of $2.56 \mathrm{U} / \mathrm{ml}$ was obtained at $\mathrm{pH}(6.5)$, temperature $\left(35^{\circ} \mathrm{C}\right)$, incubation time $(24 \mathrm{hr})$ and inoculum concentration (4\%) in submerged fermentation. Singh and Kumari (2016) isolated starch degrading bacteria from soil samples collected from different environment sources (Banana, Potato and Sugarcane field samples). Out of 10 isolated bacterial strains, Bacillus sp. B3 gave positive starch hydrolysis and thus was suggested for industrial application like starch modification with better efficiency with the increase in temperature.

Similarly, Rehman and Saeed (2015) investigated 39 amylase producing Bacillus sp. from soil of which Bacillus sp. stain AS-2 was reported to have highest enzyme activity (3179.62 IU/ml/min). Vaseekaran et al (2015) isolated, identified and characterised thermo- stable amylolytic bacteria from contaminated soil with decaying materials i.e. kitchen waste and bakery waste soil etc. Their investigation revealed one strain identified as Bacillus licheniformis with highest $\alpha$-amylase activity $(7.0 \pm 0.21 \mathrm{Um} / \mathrm{L})$ at $24 \mathrm{~h}$ and enzyme showed neutral optimum $\mathrm{pH}$ and temperature $\left(90^{\circ} \mathrm{C}\right)$ without additives.

Dash et al (2015) also identified and optimized new B. subtilis strain BI19 that produced appreciable amount of amylase. Singh et al (2012) produced extracellular amylase by Bacillus sp. which was optimized in a submerged fermentation as maximum enzyme activity was obtained at $35^{\circ} \mathrm{C}$ and $\mathrm{pH} 7$ and after $10 \mathrm{~h}$ inoculation. In submerged fermentation, contents of a synthetic medium are very expensive and uneconomical, so there is urgent need of these to be replaced with more economically available agricultural, industrial and domestic by products which are used as substrates for SSF to produce enzymes in economical way.

SSF holds tremendous potential for the production of enzymes in view of its economic and engineering advantages. It can be of particular relevance in those processes where a crude fermented product may be used as an enzyme source (Pandey et al 1999). The major critical factors affecting microbial synthesis of enzymes in a SSF system include selection of a suitable substrate and strains, particle size of the substrate, inoculum concentration, moisture level of the substrate, temperature and pH. Selection of an appropriate solid substrate plays an important role in the development of efficient SSF processes (Lonsane et al 1985). Sexena and Singh (2011) carried out solid state fermentation using various agroindustrial wastes with best amylase producing strain isolated from soil. Different physicochemical conditions were varied for maximum enzyme production. The iso- 
Table 1. Over view of amylase producing bacterial and fungal strains (Sundarram et al 2014)

\begin{tabular}{|c|c|c|}
\hline Amylolytic Microorganism type & Fermentation type & Reference \\
\hline B.amyloliquefaciens & SSF & Oboh (2005) \\
\hline Bacillus licheniformis & SSF & Babu et al (1995) \\
\hline Bacillus coagulans & SSF & Prakash et al (2009) \\
\hline B. polymyxa & SSF & Prakash et al (2009) \\
\hline B. mesentericus & SSF & Prakash et al (2009) \\
\hline B. vulgarus & SSF & Prakash et al (2009) \\
\hline B. megaterium & SSF & Prakash et al (2009) \\
\hline Bacillus licheniformis GCB-U8 & SmF & Sodhi et al (2005) \\
\hline Bacillus sp. PS-7 & SSF & Ramesh and Lonsane (1990) \\
\hline Bacillus licheniformis M27 & SSF & Amoozegar et al (2003) \\
\hline Halobacillus sp MA-2 & SmF & Gomes and Gomes (2003) \\
\hline Halomonas meridiana & SmF & Kathiresan and Manivannan (2006) \\
\hline Rhodothermus marinus & SmF & Anto et al (2006) \\
\hline Bacillus cereus MTCC 1305 & SSF & Sivaramakrishnan et al (2007) \\
\hline \multicolumn{3}{|c|}{ Fungi } \\
\hline Aspergillus oryzae & SSF & Leveque et al (2000) \\
\hline Penicillium fellutanum & SmF & Erdal et al (2010) \\
\hline Thermomyces lanuginosus & SSF & Upgade et al (2011) \\
\hline Aspergillus niger & SSF, Smf & Yang and Wang (1999) \\
\hline Penicillium roquefortii & SSF & Sivaramakrishnan et al (2006) \\
\hline Streptomyces rimosus & SSF, Smf & Sudo et al (1994) \\
\hline Aspergillus kawachii & SSF, Smf & Balkan and Ertan (2007) \\
\hline Penicillium chrysogenumm & SSF & Sindhu et al (2009) \\
\hline Penicillium janthinellum (NCIM 4960) & SSF & Prakasham et al (2007) \\
\hline Aspergillus awamori & SmF & Siqueira et al (1997) \\
\hline Pycnoporus sanguineus & SSF & Saito et al (1975) \\
\hline
\end{tabular}

late produced about 5400 units/g of amylase at 1:3 moisture content, 20\% inoculum concentration, temperature $\left(50^{\circ} \mathrm{C}\right), \mathrm{pH} 6.0$ and after $72 \mathrm{~h}$ of incubation with Mustard Oil seed cake as the substrate. Similarly, Maity et al (2015) utilized Bacillus subtilis (ATCC 6633) for production of alpha amylase by optimization of the fermentation media. They also reported that $80 \%$ retention of alpha amylase activity comparable to purified porcine pancreatic amylase in the presence of drastic conditions of temperature $\left(60^{\circ} \mathrm{C}\right), \mathrm{pH}(6-11)$, detergents and utilized various industries like detergent, food and paper industries.
RSM is a statistical and mathematical tool for designing experiments, building models, evaluating the combined effect of many variables to investigate the optimum conditions for desirable response with reduced number of required experiments. Tanyildizi et al (2005) combined effects of macronutrients of media on $\alpha$-amylase production by Bacillus sp. using response surface methodology. The results showed that yeast extract had no effect on $\alpha$-amylase production. The optimal combinations of media constituents for maximum $\alpha$-amylase production were determined as $17.58 \mathrm{~g} / \mathrm{l}$ starch, 12.37\% 
(v/v) glycerin and $8.77 \mathrm{~g} / \mathrm{l}$ peptone. Similarly, Sun et al (2011) optimized the process parameters through the statistical approach for the production of alpha amylase by Bacillus subtilis ZJF-1A5 in submerged fermentation. Among the variables screened, the temperature and time were most significant and also showed a positive interaction. The optimum levels were: temperature $\left(35.8^{\circ} \mathrm{C}\right), \mathrm{pH}(5.03)$ and time (54hrs). Under these conditions $\alpha$-amylase yield was $191.15 \mathrm{U} / \mathrm{ml}$.

Purification is a key step in the enzymes production where residual cell proteins and contaminants are removed. The methods used to purify amylases can vary considerably, but most purification protocols involve a series of steps (Sun et al 2010). Aassar et al (1992) performed the acetone fractionation of Bacillus lentus culture filtrate yielded the highest $\alpha$-amylase activity and $66.6 \%$ fraction reached 13-fold that of the crude enzyme preparation. $\alpha$-amylase from Bacillus licheniformis was purified 6-fold with a yield of 38\% using by two gel filtration chromatography steps on Sephadex G-100 and Superose 12 column (Bozic et al 2011). In addition to the classical chromatographic techniques, immunoaffinity chromatography has been applied for the preparation of highly purified amylases (Jang et al 1994). Abdu et al (2011) identified a novel Bacillus cereus MS6 strain, which could produce extra cellular amylase that was purified by DEAE-Cellulose anion exchange and sepharose gel filtration chromatography, resulting in high yield of enzyme. The native protein showed a molecular mass of $149 \mathrm{kDa}$ being composed of a homo dimer of 78 kDa polypeptide by SDS-PAGE.

\section{Biochemical characterization of alpha amylase}

When defining the proposed unit of activity for any enzyme, the International Unit of Biochemistry stated that reaction conditions should be specified as optimal. This implies that enzyme activities are only valid within a range of physical properties. Therefore, optimum conditions for producing maximum enzyme activities need to be determined.

Amenaghawon et al (2016) conducted a study of enzymatic hydrolysis towards cocoyam starch and found that the rate of hydrolysis was faster at a higher temperature. Therefore, there has been a need and continual search for more thermophilic and thermostable $\alpha$-amylase (Burhan et al 2003). Aassar et al (1992) observed that the pure enzyme from Bacillus lentus was stable at higher temperatures in the presence of its substrate. It exhibited an optimum reaction temperature of $70^{\circ} \mathrm{C}$ and retained about $42^{\circ}-70^{\circ} \mathrm{C}$ of its activity at $85^{\circ} \mathrm{C}$ and even at higher temperatures the enzyme still showed some activity. Weemaes et al (1996) studied stability of $\alpha$-amylases produced by $B$. amyloliquefaciens, $B$. licheniformis and $B$. stearothermophilus under com- bined high temperature and pressure and the results indicated that $\alpha$-amylase produced by $B$. licheniformis was the most stable enzyme.

The $\mathrm{pH}$ of a solution affects the structure and activity of enzymes. Khanna (2010) explained that pH has an effect on the state of ionization of acidic or basic amino acids. If the state of ionization of amino acids in a protein is altered then the ionic bonds that help to determine the 3D shape of the protein got changed. Sodhi et al (2005) reported that $\alpha$-amylase of Bacillus sp. PS-7 strain showed $\mathrm{pH}$ optima at $\mathrm{pH} 6.5$ and displayed 87 and 52\% of peak activity at pH 6.0 and 5.0, respectively. Elkhalil and Gaffar (2011) analysed the pH activity profile of Bacillus sterothermophilus which showed an optimum activity at $\mathrm{pH} 7$ compared to the $B$. acidocaldarius, with an activity optimum at $\mathrm{pH}$ 6. The relative activities of Bacillus sterothermophilus at $\mathrm{pH} 9$ and 10 were about 1.5 and 4.5 times higher than those of the B. acidocaldarius. Similary, Qader et al (2006), who stated that the optimum pH of Bacillus sp. AS-1 was around 7.5. Most of amylases are known to be metal ion-dependent enzymes, namely divalent ions like $\mathrm{Ca}^{2+}, \mathrm{Mg}^{2+}, \mathrm{Mn}^{2+}$, $\mathrm{Zn}^{2+}$ and $\mathrm{Fe}^{2+}$ etc (Pandey et al 2000). Najafi and Kembhavi (2005) studied the effects of chemical modifiers on $\alpha$-amylase enzyme activity from marine Vibrio sp. The results suggested the involvement of amino acids such as Lys, Trp, Asp/Glu and His in enzyme activity. It also has been reported that heavy metal ions such as $\mathrm{Hg}^{2+}$, $\mathrm{Ag}^{2+}$ and $\mathrm{Cu}^{2+}$ inhibited amylase activity (Dey et al 2002).

Asoodeh et al (2013) studied the effect of metal ions $\left(\mathrm{K}^{+}, \mathrm{Na}^{+}, \mathrm{Zn}^{2+}, \mathrm{Ba}^{2+}, \mathrm{Mg}^{2+}, \mathrm{Ca}^{2+}, \mathrm{Fe}^{2+}\right.$ and $\left.\mathrm{Hg}^{2+}\right)$, on the enzyme activity. Among the testified metal ions, $\mathrm{Mg}^{2+}$, $\mathrm{Fe}^{2+}$ and $\mathrm{Ba}^{2+}$ increased the amylase activity, while $\mathrm{Hg}^{2+}$ and $\mathrm{Zn}^{2+}$ were established to inhibit enzyme activity. Asoodeh et al (2013) determined the kinetic parameters by incubating $0.1 \mathrm{ml}$ of enzyme $(0.1 \mathrm{mg} / \mathrm{ml})$ in the presence of $0.9 \mathrm{ml}$ starch at different concentrations (0.1-1.2 $\% \mathrm{w} / \mathrm{v})$. As estimated from Michaelis-Menten equation the values of $\mathrm{Km}$ and Vmax for starch as substrate were $4.5 \pm 0.13 \mathrm{mg} / \mathrm{ml}$ and $307 \pm 12 \mathrm{lM} / \mathrm{min} / \mathrm{mg}$, respectively.

\section{SIGNIFICANCE OF FUNGAL GLUCOAMYLASE (GA) IN STARCH HYDROLYSIS}

Glucoamylase (GA), also known as amyloglucosidase (EC 3.2.1.3), is an inverting and exo-acting enzyme, capable of hydrolyzing $\alpha-1,4$ glycosidic linkages in soluble starches and related oligosaccharides with the inversion of the anomeric configuration to produce glucose. In addition to acting on $\alpha-1,4$ linkages, the enzyme slowly hydrolyzes $\alpha-1,6$ glycosidic linkages of starch (Weil et al 1954; Fierobe et al 1998). The widely accepted mechanism of hydrolysis involves proton transfer from the catalyst to the glycosidic oxygen of the scissile bond. 
A general acid-base catalyst (McCarter and Withers, 1994; Sinnot, 1990; Tanaka et al 1994) donates hydrogen to the glucosidic oxygen and a catalytic base guiding the nucleophilic attack by a water molecule on the $\mathrm{C}-1$ carbon of the glucose moiety.

\section{Microbial production of glucoamylase}

Traditionally, glucoamylase have been produced by SmF. The development of microbial strains, media composition and process control has contributed to the achievement of high levels of extracellular glucoamylase. Banakar et al (2012) investigated the amylase production from fungal species by submerged fermentation $(\mathrm{SmF})$. The Production medium was supplemented with $2 \%(\mathrm{w} / \mathrm{v})$ soluble starch incubated under shake culture at a temperature of $28 \pm 1^{\circ} \mathrm{C}$, pH-7.0 for 7 days. Maximum amylolytic activity was recorded with crude enzyme at 3 rd day of incubation by Penicillium sp. $(0.87 \pm 0.05 \mathrm{U} /$ $\mathrm{mL})$ followed by Penicillium chrysogenum $(0.69 \pm 0.05 \mathrm{U} /$ $\mathrm{mL})$, Aspergillus candidus $(0.67 \pm 0.03 \mathrm{U} / \mathrm{mL})$, Aspergillus fumigatus $(0.066 \pm 0.06 \mathrm{U} / \mathrm{mL})$ and at 7 th day of incubation was by Penicillium sp. $(1.13 \pm 0.03 \mathrm{U} / \mathrm{mL})$ followed by Penicillium chrysogenum $(1.12 \pm 0.004 \mathrm{U} / \mathrm{mL})$. Wang et al (2008) investigated food waste (FW) as potential substrate for the glucoamylase production by Aspergillus niger UV-60 under submerged fermentation. They reported that optimum concentration of 2.50\% (dry basis), smashed food waste (smashed-FW) produced glucoamylase of $126 \mathrm{U} / \mathrm{ml}$ after $96 \mathrm{~h}$ of incubation, whereas $137 \mathrm{U} / \mathrm{ml}$ of glucoamylase could be achieved within the same time from raw food waste (raw-FW) of 3.75\%.

Recently, Okwuenu et al (2017) optimized the production of glucoamylase from Aspergillus niger in a submerged fermentation process using amylopectin from guinea corn starch as the sole carbon source. Specific activities for crude enzymes were found to be $729.45 \mathrm{U} /$ $\mathrm{mg}$ and $1046.82 \mathrm{U} / \mathrm{mg}$ at five and twelve days harvested enzymes, respectively. Benassi et al (2014) investigated the production of glucoamylase from Aspergillus phoenicis in Machado Benassi (MB) medium using 1\% maltose as carbon source. The maximum amylase activity was recorded with temperature $\left(60-65^{\circ} \mathrm{C}\right)$ and $\mathrm{pH}(4.5)$ after 4 days of incubation in static conditions. However, the glucoamylase costs are still too high for the establishment of a cost effective production of energy syrup.

The SSF process has potential to significantly reduce the enzyme production costs because of lower energy requirements, increased productivity, smaller effluent volumes and simpler fermentation equipment (Ellaiah et al 2002). Cereal bran flours, potato residue and other starchy waste materials have been utilized as fermentation substrate for glucoamylase production by filamentous fungi (Joshi et al 1999; Biesebeke et al 2005). Glucoamylase production by $A$. niger was extensively studied using wheat bran in SmF and SSF by Kaur et al (2003). Wheat bran, paddy husk, rice processing wastes or other starch containing wastes have gained importance as supports for fungal growth during glucoamylase production (Arasartnam et al 2001).

Sethi and Gupta (2015) isolated amylolytic fungi from soil and identified them as Aspergillus niger, Pencillium chrysogenum, Microsporium sp. and Fusarium sp on the basis of morphological, biochemical characterization and starch hydrolysis assay, of these Pencillium chrysogenum was most potent alkaline amylase producing fungi with highest enzyme activity under optimised conditions i.e $\mathrm{pH}(8.0)$, temperature $\left(45^{\circ} \mathrm{C}\right)$, wheat bran (1\%) and peptone incubated for 7 days. Indriati et al (2018) reported that 3, out of 16 thermophile bacteria produced high amylase activity in media supplemented with wheat flour@ $2 \%$ at $40-50^{\circ} \mathrm{C}$.

Zambare (2010) employed response surface methodology to optimize SSF medium and various parameters for production of glucoamylase by Aspergillus oryzae on the solid surface of rice husk, wheat bran, rice bran, cotton seed powder, corn steep solids, bagasse powder, coconut oil cake, and groundnut oil cake as substrates which resulted in a 24\% increase in the glucoamylase activity. Optimum glucoamylase production (1986 $\mu$ moles of glucose $/ \mathrm{min} / \mathrm{g}$ of fermented substrate) was observed on wheat bran supplemented with $1 \%$, (w/w) starch, 0.25\%, (w/w) urea at pH 6, 100\%, (v/w) initial moisture and $300^{\circ} \mathrm{C}$ after incubation of $120 \mathrm{hrs}$.

Kiran et al (2014) utilized food wastes such as waste bread, waste cakes, cafeteria waste, fruits, vegetables and potatoes for glucoamylase production by solid state fermentation. Response surface methodology was used to optimize the fermentation conditions for improving enzyme production and waste cake was the best substrate for glucoamylase production. The highest glucoamylase activity (108.47 U/gds) was achieved at initial pH (7.9), moisture content (69.6\% wt) and inoculum loading $5.2 \times 105$ cells/g of substrate and incubation time of 6 days. Kumar and Satyanarayana (2004) improved the glucoamylase production by a thermophilic mold Thermomucor indicae seudaticae in solid-state fermentation (SSF) by applying response surface methodology (RSM). The glucoamylase production containing wheat bran as substrate, under the conditions optimized by RSM, was $455 \pm 23 \mathrm{U} / \mathrm{g}$ of dry moldy bran (DMB) is higher than those reported in the literature.

Similarly, Banerjee and Ghosh (2017) applied response surface methodology, a statistical tool for the optimization of glucoamylase production by Aspergillus niger in solid state fermentation using garden pea peel as a substrate. The optimized fermentation composition was incubation time: 5 days; incubation temperature: $30^{\circ} \mathrm{C}$; and substrate amount: $3 \mathrm{~g}$, which resulted in GA produc- 
tion of 90.1728 Ugds-1. In literature also, Alam et al (2014) examined the effect of process parameters $(\mathrm{pH}$, inoculum concentration and agitation speed) on glucoamylase production from bitter cassava by Aspergillus niger using response surface methodology (RSM).Utmost glucoamylase production of $38.30 \mathrm{U} / \mathrm{ml}$ was attained under optimized conditions of $\mathrm{pH}$, inoculum concentration and agitation speed of 4.8, $3.7 \%(\mathrm{v} / \mathrm{v})$ and $260 \mathrm{rpm}$, respectively. Both the experimental and predicted results were in agreement with each other as values of 38.30 $\mathrm{U} / \mathrm{ml}$ and $38.07 \mathrm{U} / \mathrm{ml}$ were obtained respectively thus, confirmed the validity of the developed model as well as attainment of the optimal points.

Glucoamylase from various sources have been purified extensively by the procedures using several types of column fractionations including ion-exchange, hydrophobic and gel filtration chromatographic steps. Bagheri et al (2014) investigated a glucoamylase enzyme from Aspergillus niger and purified it using fractionation, followed by anion-exchange chromatography. The results revealed that molecular mass of glucoamylase enzyme was estimated to be $62,000 \mathrm{Da}$, using SDS-PAGE and $57151 \mathrm{Da}$, based on mass spectrometry. Slivinski et al (2011) produced glucoamylase by Aspergillus niger in solid-state fermentation. The enzyme was partially purified by ammonium sulphate precipitation and ion exchange and gel filtration chromatographies. Its molecular mass was estimated as $118.17 \mathrm{kDa}$ by electrophoresis. Okwuenu et al (2017) investigated the production of glucoamylase from Aspergillus niger in a submerged fermentation process using amylopectin fractionated from guinea corn starch as the carbon source. The crude enzyme with specific activity $729.45 \mathrm{U} / \mathrm{mg}$ was purified to the level of gel filtration (using sephadex G-100) via ammonium sulphate (70\%) precipitation and specific activities were found to be $65.98 \mathrm{U} / \mathrm{mg}$ and $180.52 \mathrm{U} /$ $\mathrm{mg}$ respectively.

\section{Biochemical characterization of glucoamylase}

Many glucoamylases derived from fungi were functionally active at thermophilic temperatures, usually 50 to $60{ }^{\circ} \mathrm{C}$. The enzymes from Aspergillus niger NRRL 330 and Aspergillus awamori var. kawachi were optimally active at $50{ }^{\circ} \mathrm{C}$ and $60^{\circ} \mathrm{C}$, respectively whereas GAs of Arthrobotrys amerospora were optimally active at $55.8^{\circ} \mathrm{C}$ (Spinelli et al 1996; Norouzian et al 2000). Ali and Hossain (1991) reported that the optimum temperature for the action of the glucoamylase was $60^{\circ} \mathrm{C}$. The enzyme was stable at temperatures between 40 and $60^{\circ} \mathrm{C}$ with essentially no loss of activity in $30 \mathrm{~min}$.

The rate of an enzyme catalysed reaction varies with $\mathrm{pH}$ of the system. Slivinski et al (2011) produced glucoamylase enzymes by Aspergillus niger in SSF and partially purified and characterized them biochemically. The partially purified enzyme had an optimum $\mathrm{pH}$ (4.5-5.0) and temperature $\left(60^{\circ} \mathrm{C}\right)$, with an average activity 152.85 $\mathrm{U} \mathrm{ml}^{-1}$. Jebor et al (2014) purified and characterized glucoamylase enzyme from Aspergillus niger The purified glucoamylase (A\&B) had a maximum activity at $\mathrm{pH}(8$ and6.5) and temperature $\left(40^{\circ} \mathrm{C}\right.$ and $\left.30^{\circ} \mathrm{C}\right)$ respectively. It was also found that the $\mathrm{K}_{\mathrm{m}}$ and $\mathrm{V}_{\max }$ value of glucoamylase (B) were $(2.8 \mathrm{mM}$ and $9.8 \mathrm{mM} / \mathrm{min})$ respectively using different concentration of starch. Banerjee and Ghosh (2017) used garden pea peel as a substrate in SSF by Aspergillus niger for the production of glucoamylase. The $\mathrm{K}_{\mathrm{m}}$ and $\mathrm{V}_{\max }$ for glucoamylase were $0.387 \mathrm{mg}$ of soluble starch $\mathrm{ml}^{-1}$ and $35.03 \mathrm{U}^{-1} \mu l^{-1} \mathrm{~min}^{-1}$ respectively.

Okwuenu et al (2017) obtained Lineweaver-Burk plot of initial velocity at different substrate concentrations and $\mathrm{K}_{\mathrm{m}}$ and $\mathrm{V}_{\max }$ of the enzyme were found to be 770.75 $\mathrm{mg} / \mathrm{ml}$ and $2500 \mu \mathrm{mol} / \mathrm{min}$ respectively. Vivian et al (2014) reported the activation of glucoamylase from Aspergillus phoenicis by manganese $\left(\mathrm{Mn}^{2+}\right)$ and calcium $\left(\mathrm{Ca}^{2+}\right)$ ions. The rise in glucoamylase activity caused by these metal ions $\left(\mathrm{Ca}^{2+}, \mathrm{Zn}^{2+}, \mathrm{Co}^{2+}, \mathrm{Fe}^{2+}\right.$ and $\mathrm{Mn}^{2+}$ ions) could be attributed to the ability of these metals ions to serve as an electron donor or Lewis acid as they participate directly in the catalytic mechanism of the enzyme.

\section{SYNERGISTIC USE OF ALPHA AMYLASE AND GLUCOAMYLASE IN STARCH HYDROLYSIS}

Kunamneni and Singh (2005) prepared crude amylases from Bacillus subtilis ATCC 23350 and Thermomyces lanuginosus ATCC 58160 under SSF. The effect of various process variables was studied for maximum conversion efficiency of maize starch to glucose using crude amylase preparations. Doses of pre-cooking and postcooking amylase, glucoamylase and saccharification temperature were found to produce maximum conversion efficiency and were optimization of fermentation process. Maximum conversion efficiency (96.25\%) were recorded at pre-cooking and post-cooking $\alpha$-amylase (2.243 and $3.383 \mathrm{U} / \mathrm{mg}$ solids) respectively and glucoamylase $(0.073 \mathrm{U} / \mathrm{mg}$ solids) at saccharification temperature $\left(55.1^{\circ} \mathrm{C}\right)$. Soni et al (2003) isolated Bacillus sp. AS-1 and Aspergillus sp. AS-2, producing very high titres of thermostable $\alpha$-amylase and glucoamylase (198 950 and $3426 \mathrm{U} / \mathrm{g}$ fermented dry matter, respectively), during SSF of wheat bran. Both enzymes were active and stable over a wide range of temperature and $\mathrm{pH}$. $\alpha$-Amylase exhibited a high liquefying efficiency (96\%) while glucoamylase revealed high saccharification efficiency (87\%), in a $15 \%$ starch solution, at $50.8^{\circ} \mathrm{C}$. When used in combination, these enzymes could effectively hydrolyzed wheat mash revealing a maximum conversion efficiency (96\%). 
Sodhi et al (2005) used alpha amylase from Bacillus sp. PS-7 in combination with a standard commercial amyloglucosidase (AMG), BioglucanaseTM in the hydrolysis of malt starch for alcohol production. It was found that the laboratory alpha amylase preparation worked very well in the synergistic use with AMG, with over all mashing efficiency (89.0\%), overall efficiency $(79.5 \%)$ and alcohol yields (25.43 \%) and also competed well with the commercial alpha -amylase preparation, PromaltTM, commonly used in combination with BioglucanaseTM, a commercial amyloglucosidase, for malt starch hydrolysis in Indian breweries and distilleries.

\section{ETHANOLIC FERMENTATION OF WHEAT HYDROLYSATE}

Direct fermentation of starch using amylolytic microorganism offers a better alternative to the conventional multistage employing commercial amylases for liquefaction and saccharification followed by yeast fermentation (Verma et al 2000; Knox et al 2004). By using this amylolytic microorganism in direct fermentation, the ethanol production cost can be reduced via recycling of microorganism back to fermenters, thereby maintaining a high cell density, which facilitates rapid conversion of substrate into ethanol. However, there are very few types of amylolytic yeasts that are capable of efficiently hydrolyzing starch. Recombinant microbes and mix of amylolytic microorganism with glucose fermenting yeast in co-culture fermentation can be used to enhance starch hydrolysis and fermenting efficiency.

Review of literature has revealed that ability of yeast strains to achieve high level of ethanol strongly depends on the nutritional conditions and protective functions. The immobilization of fermenting organism for the bioethanol production has been greatly explored as a strategy to overcome substrate and product inhibition and to improve the ethanol tolerance (Ljiljanamojovic et al 2009 In Separate Hydrolysis and Fermentation (SHF) configuration, the enzyme production, hydrolysis of biomass, hexose and pentose fermentation are carried out in separate reactors and at their optimum fermenting conditions (Lynd et al 2002).

The disadvantages of SHF led to the development of Simultaneous Saccharification and Fermentation (SSF) process (Wright et al 1988). It is generally accepted that integration of the enzymatic saccharification and fermentation step which are carried out in one vessel so called simultaneous saccharification and fermentation (SSF) process could reduce the production cost and process time compared to conventional separate hydrolysis and fermentation (SHF) process (Mojovic et al 2006). The presence of yeast or bacteria along with enzymes minimizes the sugar accumulation in the vessel because the fermenting organism immediately consumes the released sugars. Since sugar produced during starch breakdown slows down $\alpha$-amylase action, higher rates, yields and concentrations of ethanol are possible using SSF rather than SHF, at lower enzyme loading. Additionally, the presence of ethanol makes the mixture less vulnerable to contamination by unwanted microorganisms, which is a frequent burden in case of industrial processes (Bai et al 2008).

In literature, Kumar et al (1999) used simultaneous saccharification and fermentation to produce ethanol from starch of damaged quality wheat and sorghum grains by employing crude amylase preparation from $B$. subtilis VB2 and an amylolytic yeast strain $S$. cerevisiae VSJ4. They reported that 25\% concentration of damaged wheat and sorghum starch was found to be optimum for damaged wheat and sorghum starch yielding $4.40 \% \mathrm{~V} / \mathrm{V}$ and $3.50 \% \mathrm{~V} / \mathrm{V}$ ethanol respectively. Whereas 25\% raw starch of fine quality wheat and sorghum grains gave an yield of 5.60\%V/V and 5.00\%V/V respectively. Similarly, simultaneous saccharification and fermentation (SSF) of damaged grains of sorghum and rice was conducted using Aspergillus niger (NCIM 1248) and Saccharomyces cerevisiae VSJl. More yield of ethanol was produced from the damaged sorghum $(2.90 \% \mathrm{v} / \mathrm{v})$ than damaged rice $(2.09 \% \mathrm{v} / \mathrm{v})$ under optimal fermentation conditions (Kumar et al 1998). Recent research studies on Simultaneous Saccharification and Fermentation (SSF) of damaged corn grains using symbiotic strains of starch digesting Aspergillus niger (NCIM 1248 and sugar fermenting Saccharomyces cerevisiae (MTCC 170) revealed that SSF of damaged corn grains yielded maximum ethanol concentration of $4.24(\mathrm{~g} / 100 \mathrm{ml})$ whereas fine corn grains yielded $(6.3 \mathrm{~g} / 100 \mathrm{ml})$ ethanol (Gawande and Patil 2018).

Waste potato mash was chosen as a renewable carbon source for ethanol fermentation because it is relatively inexpensive compared with other feedstock considered as food sources. Izmirlioglu et al (2012) optimized the parameters for ethanol fermentation using response surface methodology to achieve maximum ethanol production. The study revealed that $\mathrm{pH}$ (5.5) and 3\% inoculum size were optimum for maximum ethanol concentration. The maximum bio-ethanol production rate was attained at the optimum conditions of $30.99 \mathrm{~g} / \mathrm{L}$ ethanol. Hence, waste potato mash was found as a promising carbon.

\section{Current and future perspectives}

This review paper investigated the potential for utilization of spoiled wheat grains for bioethanol. The main source for ethanol production in India is still molasses which single handedly cannot sustain the demand. Hence, there is need to look for alternate substrates for meeting the increasing ethanol production. Secondly, 
thermostable alpha amylases are a more recent research which may reduce energy on cooling the mash prior to saccharification. It is also imperative to standardize the mash composition by optimizing solid-liquid ratio, addition of protease etc and mash environment (optimum temperature and $\mathrm{pH}$ ). Further, to lower down the cost of fermentation recombinant glucoamylase-expressing yeasts were utilized to improve the efficiency of starch fermentation. The process cost may be further reduced by using this process as it reduces the time as well as energy by using two different vessels for saccharification and fermentation besides lowering the chances of contamination.

Genetic engineering approaches should be more focused on developing new improved strains with higher substrate tolerance and improved production kinetics. Though using damaged grains will incur lower substrate cost, mashing involves costly commercial saccharification and enzymes which may also be taken care of by using indigenous culture of Bacillus subtilis, Bacillus circulans, Bacillus cereus etc for $\alpha$-amylase and Aspergillus sp. such as Aspergillus niger, Aspergillus oryzae etc for glucoamylase. Thus, utilization of especially damaged and spoiled wheat grains pave better way for commercialization of bioethanol production from an economical perspective.

\section{REFERENCES}

Aassar S A E, Omar S H, Gouda M K, Ismail A M, Abdel-Fattah A F (1992) Purification of $\alpha$-amylase from Bacillus lentus cultures. Appl Microbiol Biotechnol 38: 312-314.

Abu T F A, Enujiugha V N, Sanni D M and Bamidele O S (2014) Purification and characterisation of $\alpha$-amylase from Bacillus subtilis isolated from fermented African locust bean (Parkia biglobosa) seeds. Int J LifeSc Bt Pharm Res 3(4): 1-18.

Alam M Z, Khalaf A, Salleh H M and Salihu A(2014) Process Optimization of Glucoamylase Production by Aspergillusniger Using Bitter Cassava (Manihotes culenta). J Environ Biol 8(17): 42-47.

Albani J R (2008) Principles and Applications of Fluorescence Spectroscopy. Oxford, UK: Blackwell.

Ali S and Hossain H (1991) Characteristics of glucoamylase from Aspergillus terreus. J Appl Microbiol 71: 144-6.

Amenaghawon N, Osagie E and Ogbeide S (2016) Optimisation of Combined Acid and Enzymatic Hydrolysis of Cocoyam Starch to Produce Fermentable Hydrolysate. Pertanika J Sci Technol 24(1): 123-36.

Amoozegar M A, Malekzadeh F and Malik K A (2003) Production of amylase by newly isolated moderate halophile Halobacillus sp. Strain MA-2. J Microbiol 52: 353-59.

Anonymous (2017) FCI wheat worth Rs 700 crores got damaged till Mar 2016 in Punjab: CAG (https://www.tribuneindia. com/.../punjab/fci-wheat...damaged...punjab.../447086.html)
Anto H, Trivedi U and Patel K (2006) $\alpha$-Amylase production by Bacillus cereus MTCC 1305 using solid-state fermentation. Food Sci Biotechnol 44 (2): 241-45.

Arasaratnam V, Mylvaganam K and Balasubramaniam K (2001) Improvement of glucoamylase production by Aspergillus niger in solid-state fermentation with paddy husk as support. J Food Sci Technol 38: 334-38.

Asoodeh A, Alemi A, Heydari A and Akbari J (2013) Purification and biochemical characterization of an acidophilic amylase from a newly isolated Bacillus sp. Extremophiles 17: 339-48.

Awasthi P, Shrivastava S, Kharkwal A C and Verma A (2015) Biofuel from agricultural waste. Int J Curr Microbiol App Sci 4: 470-77.

Babu K R and Satyanarayana T (1995) $\alpha$-Amylase production by thermophilic Bacillus coagulans in solid state fermentation. Process Biochem 30 (4): 305-09.

Bagheri A, Khodarahmi R,Mostafaie A(2014)Purification and biochemical characterization of glucoamylase from a newly isolated Aspergillus niger: Relation to starch processing. Food Chem 161: 270-278.

Bai F W, Anderson W A and Moo-Young M (2008) Biotechnol Adv 26: 89-105.

Balkan B and Ertan F (2007) Production of a-amylase from Penicillium chrysogenum under solid-state fermentation by using some agricultural by-products. Food Technol Biotechnol 45: 439-42.

Ballesteros I, Negro M J, Oliva J M., Cabanas A, Manzanares $\mathrm{P}$ and Ballesteros M (2006) Ethanol production from steamexplosion pretreated wheat straw. Appl Biochem Biotechnol 130: 496 -508.

Banakar S P, Thippeswamy, Thirumalesh and Naveenkumar K (2012) Isolation, Production and Partial Purification of Fungal Amylase from Forest Soils of Bhadra Wildlife Sanctuary, Western Ghats. J Pharm Biotech and Microbiol 20(3): 1-8.

Banerjee S and Ghosh U (2017) Production and Characterization of Glucoamylase by Aspergillus niger. Appl Food Biotechnol 4(1): 19-26.

Banerjee S and Ghosh U (2017) Production and Characterization of Glucoamylase by Aspergillus niger. Appl Food Biotechnol 4(1): 19-26.

Barfoed H (1967) Die Verwendung von Enzymenbei der Herstellung von Dextrose und Starkes irup. Starke 19: 2-8.

Bej B, Basu R K and Ash S N (2008) Kinetic study on acid catalyzed hydrolysis of starch. J Sci Ind Res 67: 295-98.

Belboom S, Bodson B and Leonard A (2015) Does the Production of Belgian Bioethanol Fit with European Requirements on GHG Emissions Case of Wheat. Biomass Bioenergy 74: 5865.

Benassi V M, Pasin T M, Facchini1, Joao J A and Lourdes M D (2014) Novel glucoamylase activated by manganese and calcium produced in submerged fermentation by Aspergillus phoenicis. J Basic Microbiol 54: 333-39. 
Biesebeke R, Record E, van Biezen N, Heerikhuisen M, Franken A, Punt P J, and Hondel C A (2005) Branching mutants of Aspergillus oryzae with improved amylase and protease production on solid substrates. Appl Microbiol Biotechnol 69: 44-50.

Bijttebier A, Goesaert H and Delcour J (2008) Amylase action pattern on starch polymers. Biologia 63: 989-99.

Bowler P, Towersey P J, Waight S G and Galliard T (1985) Minor Components of Wheat Starch and Their Technological Significance. In: Hill R D and Munck L (ed) New Approaches to Research on Cereal Carbohydrates. Pp. 71-9 Elsevier Science, Amsterdam, Holland.

Bozic N, Ruizb J, Lopez-Santinb J and Vujci Z (2011) Production and properties of the highly efficient raw starch digesting $\alpha$-amylase from a Bacillus licheniformis. Biochem Eng J 53: 203-09.

Buresova I, Sedlackova I, Famera 0 and Lipavsky J (2010) Effect of growing conditions on starch and protein content in triticale grain and amylose content in starch. $\alpha$ Plant Soil Environ 56: 99-104.

Dash B K, Rahman M M and Sarker P K (2015) Molecular identification of a newly isolated Bacillus subtilis BI19 and optimization of production conditions for enhanced production of extracellular amylase. Biomed Res Int 2015 859: 1-9.

De Almeida Siqueira E M, Mizuta K and Giglio J R (1997) Pycnoporus sanguineus: a novel source of $\alpha$-amylase. Mycol Res 101(2): 188-90.

Dey G, Palit S, Banerjee R and Maiti B R J (2002) Purification and characterization of malto oligosaccharide-forming amylase from Bacillus circulans GRS 313. Ind Microbiol Biotechnol 28: $193-200$

Dziedzic S Z and Kearsley M W (1995) Handbook of Starch Hydrolysis Products and their Derivatives DOI 10.1007/978-14615-2159-4 ISBN 978-1-4615-2159-4

EIA. 2015a. Annual energy outlook, Energy Information Administration. Washington, D.C. Available at http: //www. eia.gov/forecasts/aeo/MT_ liquid fuels. cfm (accessed on 10 August 2015)

EIA. 2015b. Net petroleum imports data- 2014, U.S Energy Information Administration. Washington, D.C. Available at http: //www.eia.gov/tools/faqs/faq.cfm?id=32\&tt=6 (accessed on 10 August 2015).

Elkhalil L and Gaffar F Y (2011) Biochemical characterization of thermophilic amylase enzyme isolated from bacillus strains. Int J Sci Nat 2(3): 616-20.

Ellaiah P, Adinarayana K, Bhavani Y, Padmaja P and Srinivasula B (2002) Optimization of process parameters for glucoamylase production under solid state fermentation by a newly isolated Aspergillus species. Process Biochem 38: 615-20.

Erdal S and Taskin M (2010) Production of alpha-amylase by Penicillium expansum MT-1 in solid-state fermentation using waste Loquat (Eriobotrya japonica Lindley) kernels as substrate. Rom Biotechnol Lett 15(3): 5342-50.

Fierobe H P, Clarke A J, Tull D and Svensson B (1998) Enzymatic properties of ceystein sulfonic acid derivative of the cat- alytic base mutant Glu400YCys of glucoamylase from Aspergillus awamori. Biochem 37: 3753-9.

Fullbrook P D (1984) The enzymatic production of glucose syrups. In: Dziedsic S Z and Kearsley M W (Eds.) Glucose Syrups: Science and Technology, pp. 65-115. Elsevier, London.

G Indriati* ; R R P Megahati, E Rosba Potency of Amylaseproducing Bacteria and Optimization Amylase Activities. IOP Conf. Series: Materials Science and Engineering 335 (2018) 012023 doi:10.1088/1757-899X/335/1/012023

Gawande S B and Patil I D (2015) A review on causes for damaged sorghum and corn grains. IJSSBT 3: 5-9.

Gawandea S and Patil I D (2018) Experimental investigation and optimization for production of bioethanol from damaged corn grains. Materials Today: Proceedings 5: 1509-17.

Gomes I, Gomes J and Steiner W (2003) Highly thermostable amylase and pullulanase of the extreme thermophilic eubacterium Rhodothermus marinus: production and partial characterization. Bioresource Technol 90(2): 207-14.

Gulten Izmirlioglu 1 and Ali Demirci Ethanol Production from Waste Potato Mash by Using Saccharomyces cerevisiae Appl. Sci. 2012, 2, 738-753; doi:10.3390/app2040738.

Hansen A C, Zhang Q and Lyne P W L (2005) Ethanol diesel fuel blends a review. Bioresource Technol 96: 277-85.

Hoseinpour H, Karimi K, Zilouei H and Taherzadeh M J (2010) Simultaneous pretreatment of lignocellulose and hydrolysis of starch in mixtures to sugars. Bioresources 5(4): 2457-69.

Hua X and Yang R (2016) Enzymes in starch processing. In: Chandrasekaran M (Ed.) Enzymes in Food and Beverage Processing, pp. 139-70. Boca Raton: CRC Press.

Hua X and Yang R (2016) Enzymes in starch processing. In: Chandrasekaran M (Ed.) Enzymes in Food and Beverage Processing, pp. 139-70. Boca Raton: CRC Press.

Indian biofuels 2016 Gain report number IN608 (https://gain. fas.usda.gov/.../Biofuels\%20Annual_New\%20Delhi_India_624-2016).

Jang S, Cheong T, Him W, Kim J and Park K (1994) Purification of Bacillus licheniformis thermostable $\alpha$-amylase by immune affinity chromatography. Korean Biochem J 27: 38-41.

Jebor M A, Ali Z A and Hassan B (2014) Purification and characterization of the glucoamylase from Aspergillus niger. Int $\mathrm{J}$ Curr Microbiol App Sci 3(1): 63-75.

Joshi V K, Pandey A and Sandhu D K (1999) Waste treatments in fermentation technology. In: Joshi V K and Pandey A (Eds.) Biotechnology: Food Fermentation. Vol. 2, Trivandrum, India: Educational Publication and Distribution, pp. 12911338.

Kathiresan K and Manivannan S (2006) Amylase production by Penicillium fellutanum isolated from mangrove rhizosphere soil. Afr J Biotechnol 5: 1-10.

Kaur P, Grewal H S and Kocher G S (2003). Production of $\alpha$ amylase by Aspergillus niger using wheat bran in submerged and solid state fermentations. Indian Journal of Microbiology. 43. $143-145$. 
Kerr R W (1944) Chemistry and industry of starch: starch, sugar and related compounds. Academic press, New York.

Khanna P (2010) Cell and Molecular Biology. I.K. International Publishing House, New Delhi.

Kiran E U, Trzcinski A P and Liu Y (2014) Glucoamylase production from food waste by solid state fermentation and its evaluation in the hydrolysis of domestic food waste. Biofuel Res J 3: 98-105.

Knox A M, Preez J C and Kilian S (2004) Starch fermentation characteristics of Saccharomyces cerevisiae strains transformed with amylase genes from Lipomyces kononenkoae and Sacchamycopsis fibuligera. Enzyme Microb Technol 34: 453-60.

Knox A M, Preez J C and Kilian S (2004) Starch fermentation characteristics of Saccharomyces cerevisiae strains transformed with amylase genes from Lipomyces kononenkoae and Sacchamycopsis fibuligera. Enzyme Microb Technol 34: 45360.

Kumar N V, Dhavala P, Goswami A and Maithel S (2006). Liquid biofuels in South Asia: resources and technologies. Asian Biotechnol Develop Rev 8: 31-49.

Kumar S and Satyanarayana T (2004) Statistical optimization of a thermostable and neutral glucoamylase production by a thermophilic mold Thermomucorindicae-seudaticae in solidstate fermentation. World J Microbiol Biotechnol 20: 895902.

Kumar S, Kiransree N and Rao L V (1999) Production of ethanol by raw starch hydrolysis and fermentation of damaged grains of wheat and sorghum. Bioprocess Eng 21: 165-68.

Kumar S, Kiransree N and Rao L V (1999) Production of ethanol by raw starch hydrolysis and fermentation of damaged grains of wheat and sorghum. Bioprocess Eng 21: 165-68.

Kunamneni A and Singh S (2005) Response surface optimization of enzymatic hydrolysis of maize starch for higher glucose production. Biochem Eng J 27: 179-90.

Kust F and Potmesilova J (2014) Situation and Outlook Report: Grain. Prague, Ministry of Agriculture of the Czech Republic. (In Czech).

Leveque E, Janecek S, Haye B and Belarbi A (2000) Thermophilic archaeal amylolytic enzymes. Enzyme Microb Technol 26(1): 3-14.

Ljiljanamojovic, Dusankapejin, Olgicagrujic, Sinisamarkov, Jelenapejin, Maricarakin, Majavukasinovic, Nikolic S, Dragisasavic (2009) Progress in the Production of Bio-ethanol on Starch Base Feed stocks. Chem Ind Chem Eng 15: 211-26.

Lonsane B K and Ramesh M V (1990) Production of bacterial thermostable $\alpha$-amylase by solid-state fermentation: a potential tool for achieving economy in enzyme production and starch hydrolysis. Adv Appl Microbiol 35: 1-56.

Lynd L R, Weimer P J, van Zyl W H, Pretorius IS microbial cellulose utilization: Fundamentals and biotechnology. Microbiol Mol Biol Rev. 2002 66(3):506-77.

Maarel M J E C, vander Veen B, Uitdehaag J C M, Leemhuis H and Dijkhuizen L (2002) Properties and applications of starch- converting enzymes of the $\alpha$-amylase family. J Biotechnol 94: 137-55.

Madsen G B, and Norman B E (1973) New speciality glucose syrups. In: Birch G G and Green L G (Eds.) Molecular Structure and Function of Food Carbohydrates, pp. 50-64. Appl. Sci., London

Maity S, Mallik S, Basuthakur M and Gupta S (2015) Optimization of Solid State Fermentation Conditions and Characterization of Thermostable Alpha Amylase from Bacillus subtilis (ATCC 6633). J Bioprocess Biotech 5: 1-7.

McCarter J D and Withers S G (1994) Mechanism of enzymatic glycoside hydrolysis. Curr Opin Struct Bio 4: 885-92.

McConnell, C. (2008). Acid Hydrolysis. Qittle. 1st April 2011, Available at http: //doyouqittle. com/2008/03/08/acid-hydrolysis/

Mojovic L, Nikolic S, Rakin M. and Vukasinovic M (2006) Production of Bioethanol from Corn Meal Hydrolyzates. Fuel 85: 1750-55.

Najafi M F and Kembhavi A (2005) One-step purification and characterization of an extracellular a-amylase from marine Vibrio sp. Enzyme Microb Technol 36: 535-39.

Norouzian D, Rostami K, Nouri I D and Saleh M (2000) Subsite mapping of purified glucoamylases I, II, III produced by Arthrobotry samerospora ATCC 34468. World J Microbiol Biotechnol 16: 155-61.

Oboh G (2005) Isolation and characterization of amylase from fermented cassava (Manihot esculenta Crantz) wastewater. Afr J Biotechnol 4: 1-10.

Okwuenu P C, Agbo K U, Ezugwu A L, Eze S 0 and Chilaka F C (2017) Effect of Divalent Metal Ions on Glucoamylase Activity of Glucoamylase isolated from Aspergillus niger. Ferment Technol 6: 141-45.

Okwuenu P C, Ezugwu A L and Chilaka F C (2017) Production and optimization of Aspergillus niger glucoamylase using amylopectin from guinea corn starch as the sole carbon source. J Sci Ind Res 52: 263-72.

Okwuenu P C, Ezugwu A L and Chilaka F C (2017) Production and optimization of Aspergillus niger glucoamylase using amylopectin from guinea corn starch as the sole carbon source. J Sci Ind Res 52: 263-72.

Pandey A, Selvakumar P, Soccol C R and Nigam P (1999) Solid state fermentation for the production of industrial enzymes. Curr Sci 77: 149-62.

Pandey A, Soccol C R and Mitchell D (2000) New developments in solid state fermentation: I-bioprocesses and products. Process Biochem 35: 1153-69.

Pomeranz Y (1988) Chemical composition of kernel structure. In: Pomeranz Y (Ed) Wheat: Chemistry and Technology, Vol I, $3^{\text {rd }}$ Edn, St Paul, MN: Am Assoc Cereal Chem, pp. 9758.

Prakash B, Vidyasagar M, Madhukumar M S, Muralikrishna G and Sreeramulu K (2009) Production, purification, and characterization of two extremely halotolerant, thermostable and 
alkali-stable amylases from Chromo halobacter sp. TVSP 101. Process Biochem 44: 210-15.

Prakasham R S, Subba Rao C, Rao R and Sarma P N (2007) Enhancement of acid amylase production by an isolated Aspergillus awamori. J Appl Microbiol 102 (1): 204-11.

Qader S A U, Bano S, Aman A, Syed N and Azhar A (2006) Enhanced production and extracellular activity of commercially important amylolytic enzyme by a newly isolated strain of Bacillus. sp. AS-1. Turk J Biochem 31(3): 135-40.

Ramprakash B and Muthukumar K (2014) Comparative study on the production of biohydrogen from rice mill wastewater. Int J Hydrogen Energy 39: 14613-21.

Raplong H H, Odeleye P 0, Hammuel C, Idoko M O, Asanato J I and Odeke E H (2014) Production of alpha amylase by Bacillus cereus in submerged fermentation. Aceh Int J Sci Technol 3(3): 124-30

Rehman A and Saeed A (2015) Isolation and screening of amylase producing Bacillus species from soil. Int J Adv Res 3: 151-64.

Renewable Fuels Association US, Global Ethanol Production, 2018. https://ethanolrfa.org/, (Accessed 9 November 2018).

Saito N A and Yamamoto K A (1975) Regulatory factors affecting alpha-amylase production in Bacillus licheniformis. Int $\mathrm{J}$ Bacteriol 121(3): 848-56.

Saxena R and Singh R (2011) Amylase production by solidstate fermentation of agro-industrial wastes using Bacillus sp. Brazilian J Microbiol 42: 1334-42.

Sethi S and Gupta S (2015) Isolation, characterization and optimization of cultural conditions for amylase production from fungi. J Biosci 9: 3356-63.

Seungdo K and Dale B E (2004) Global potential bioethanol production from wasted crops and crop residues Biomass and Bioenergy 26: 361-75

Sharon M E M, Abirami C V K and Alagusundaram K (2014) Grain Storage Management in India. Postharvest Biol Technol 2: $12-24$.

Sindhu R, Suprabha G N and Shashidhar S (2009) Optimization of process parameters for the production of a-amylase from Penicillium janthinellum (NCIM 4960) under solid state fermentation. Afr J Microbiol Res 3(9): 498-503.

Singh P and Kumari P (2016) Isolation and characterization of amylase producing Bacillus spp. from selected soil sample. IJRBS 5: 24-29.

Singh P, Gupta P, Singh R and Sharma R (2012) Factors affecting alpha amylase production on Submerged Fermentation by Bacillus sp. Int J Pharm and Life Sci 3: 2243-46.

Sinnot M L (1990) Catalytic mechanisms of enzymatic glycosyl transfer. Chem Rev 90: 1171-202.

Sivaramakrishnan S, Gangadharan D, Nampoothiri K M, Soccol C R and Pandey A (2007) Alpha amylase production by Aspergillus oryzae employing solid-state fermentation. J Sci Ind Res 66(8): 621-8.
Sivaramakrishnan S, Gangadharan D, Nampoothiri K M, Soccol C R and Pandey A (2006) $\alpha$-Amylases from Microbial Sources-An Overview on Recent Developments. Food Technol Biotech 44(2): 45-52.

Slivinski C T, Machado A V L, Iulek J, Ayub R A and Braz M M A (2011) Biochemical characterization of a Glucoamylase from Aspergillus niger produced by Solid-State fermentation. Arch Biol Technol 54(3): 559-68.

Sodhi H K, Sharma H, Gupta J K and Soni S K (2005) Production of a thermostable -amylase from Bacillus sp. PS-7 by solid state fermentation and its synergistic use in the hydrolysis of malt starch for alcohol production Process Biochem 40: 525-34.

Sodhi H K, Sharma K, Gupta J K and Soni S K (2005) Production of a thermostable $\alpha$-amylase from Bacillus sp. PS-7 by solid state fermentation and its synergistic use in the hydrolysis of malt starch for alcohol production. Process Biochem 40: 525-34.

Soni S K, Kaur A and Gupta J K (2003) A solid state fermentation based bacterial a-amylase and fungal glucoamylase system and its suitability for the hydrolysis of wheat starch. Process Biochem 39: 185-92.

Spinelli B B L, Lourdes M, Polizeli T M, Terenzi H F and Jorge J A (1996) Biochemical characterization of glucoamylase from the hyper producer exo-1 mutant strain of Neurospora crassa. FEMS Microbiol Lett 138: 173-77.

Sudo S, Ishikawa T, Sato K and Oba T (1994) Comparison of acid-stable $\alpha$-amylase production by Aspergillus kawachii in solid-state and submerged cultures. J Biosci Bioeng 77(5): 48389.

Sun H, Zhao P, Ge X, Xia Y, Hao Z, Liu J and Peng M (2010) Recent Advances in Microbial Raw Starch Degrading Enzymes. Appl Biochem Biotechnol 160: 988-1003.

Swinkels, J J M (1985). Composition and properties of commercial native starches. Starch - Stärke, 37, 1-5.

Tanaka Y, Tao W, Blanchard J S and Hehre E J (1994) Transition state structure for the hydrolysis of a-D-glucopyranosyl fluoride by retaining and inverting reaction of glycosylases. J Biol Chem 269: 32306-12.

Tanyildizi M S, Ozer D and Elibol M (2005) Optimization of $\alpha$-amylase production by Bacillus sp. using response surface methodology. Process Biochem 40: 2291-96.

Thirathumthavorn D and Charoenrein S (2005) Thermal and Pasting Properties of Acid- Treated Rice Starch. Starch/ Starke 57: 217-22.

Twidell J and Weir T (2003) Renewable Energy Resources. Taylor and Francis Group, New York, pp. 601

Upgade A, Nandeshwar A and Samant L (2011) Assessment of fungal protease enzyme from French bean using $A$. niger by Solid State Fermentation. J Microbiol Biotechnol 1: 45-51.

Vaseekaran S, Balakumar S and Arasaratnam V (2015) Isolation and identification of a bacterial strain producing thermostable $\alpha$-amylase. Tropical Agric Res 22(1): 1-11.

Verma G, Nigam P, Singh D and Chaudry K (2000) Bioconversion of starch to ethanol in a single-step process by coculture 
of amylolytic yeasts and Saccharomyces cerevisiae. Bioresour Technol 72: 261-66.

Vidal B J R (2010) Protease use in ethanol production from dry fractionated corn. Graduate College University of Illinois, Urbana-Champaign.

Vivian M B, Thiago M P, Fernanda D A, Joao A J and Maria de Lourdes T (2014) A novel glucoamylase activated by manganese and calcium produced in submerged fermentation by Aspergillus phoenicis. J Basic Microbiol 54: 333-39.

Wang Q, Wang X, Wang X H and Ma H (2008) Glucoamylase production from food waste by Aspergillus niger under submerged fermentation. Process Biochem 43: 280-86.

Wang S and Copeland L (2013) Effect of Acid Hydrolysis on Starch Structure and Functionality: A Review. Crit Rev Food Sci Nutr 55(8): 1081-97.

Weemaes C, Cordt S D, Goossens K, Ludikhuyze L, Hendrickx M, Heremans K and Tobback P (1996) High pressure, thermal, and combined pressure-temperature stabilities of a-amylases from Bacillus species. Biotechnol Bioeng 50: 4956.

Weil C E, Burch R J and Van Dyk J W (1954) An a-amyloglucosidase that produces h-glucose. Cereal Chem 31: 15058.
Wheals A E, Basso L C, Alves D M G and Amorim H V (1999) Fuel Ethanol after 25 Years. Trends Biotechnol 17: 482-87.

Wright J D, Charles E Wyman Karel Grohmann Simultaneous saccharification and fermentation of lignocellulose 1988, Volume 18, Issue 1, pp 75-90

Xiang Q, Lee Y Y and Torget R T (2004). Kinetics of Glucose Decomposition during Dilute-Acid Hydrolysis of Lignocellulosic Biomass. Appl Biochem Biotechnol 116: 1127- 39.

Xu Y and Liu H Y (2009) Development and expectation of the energy plant. Chinese Agric Sci Bull 25: 297-300.

Yan S, Wu X, Dahlberg J, Bean S R, MacRitchie F, Wilson J D and Wang D (2010) Properties of field-sprouted sorghum and its performance in ethanol production. J Cereal Sci 51: 374-80

Yang S S and Wang J Y (1999) Protease and amylase production of Streptomyces rimosus in submerged and solid state cultivations. Bot Bull Acad Sin 40: 259-65.

Yoosin S and Sorapipatana C (2007) A Study of ethanol production cost for gasoline substitution in Thailand and its competitiveness. Int J Sci Technol 12: 69-80.

Zambare V (2010) Solid State Fermentation of Aspergillus oryzae for Glucoamylase Production on Agro residues. Int J Life Sci 4: 16-25 